\title{
Effect of Spacing and Sucker Removal on Precocity of Hazelnut Seedlings
}

\author{
Shawn A. Mehlenbacher and David C. Smith \\ Department of Horticulture, 2042 Cordley Hall, Oregon State University, Corvallis, \\ OR 97331-2911
}

Additional index words. Corylus avellana, filbert, juvenility, nut breeding, tree breeding, fruit breeding

\begin{abstract}
The effect of parentage, spacing, and sucker removal on precocity of hazelnut (Corylus avellana L.) seedlings was investigated. Wider spacing $(1.2 \mathrm{vs} .0 .6 \mathrm{~m})$ within the row doubled the number of nuts per seedling in the 5 th year but had no effect on nut count in the 3rd or 4th year, nor did it affect the percentage of seedlings bearing nuts in any of the three years. Differences among the four progenies were highly significant for number of clusters, number of nuts, and percentage of seedlings bearing nuts in all years and for number of years to first fruiting. The progeny 'Barcelona' $x$ OSU 55.097 had the most bearing seedlings in, the 3rd year but was outperformed by 'Casina' $\times$ OSU 55.129 in the 4th and 5th years. Number of years to first fruiting varied from 4.3 for 'Casina' $\times$ OSU 55.129 to 5.2 for 'Tombul' $\times$ 'Tonda di Giffoni'. Sucker removal increased both the percentage of seedlings bearing nuts and the number of nuts per seedlings, but the difference was not significant until the 5th year. Sucker removal reduced the length of the juvenile phase by 3 months. The use of precocious parents was more effective than sucker removal in shortening the juvenile period, while sucker removal and wide spacing within seedling rows increased the number of nuts produced by seedlings in the 5th year. Selection of seedlings for early initiation of bearing will shorten the breeding cycle, and the resulting new cultivars will be precocious when planted in commercial orchards.
\end{abstract}

Juvenility is a major impediment in the genetic improvement of tree fruit and nut species because it increases the length of the breeding cycle. The response to selection per year is lower and the cost per unit of genetic improvement is higher in proportion to the length of the juvenile period (Hansche, 1983). Previous research, summarized by Zimmerman (1972), has shown that the length of the juvenile period is influenced by genetic and environmental factors. Genetic differences, expressed as general combining abilities of parent cultivars, have been demonstrated in several species (Bell and Zimmerman, 1990; Blazek, 1985; Way, 1971), and gene action appears to be primarily additive. In apple (Malus domestics Borkh.) and pear (Pyrus communis L.), the length of the adult vegetative period of grafted trees of the parents is a good measure of their ability to transmit precocity (Visser, 1965), and precocious seedlings, when propagated by budding, produce precocious trees (Visser and DeVries, 1970).

Several environmental factors affect the length of the juvenile period. In general, seedlings start to flower and bear fruit earlier if grown under conditions that induce rapid growth. By providing ideal conditions in the greenhouse, Aldwinckle (1975) was able to induce flowering in apple seedlings in 16 months rather than the usual 8 years in the orchard. Wide spacing in seedling rows also promotes early fruiting. Way (1971) demonstrated that wide spacing of apple seedlings within the row (0.9 vs. 0.3 $\mathrm{m})$ resulted in a higher fruiting percentage by their 11th year, but questioned whether this was efficient use of land. A similar benefit from wide spacing was demonstrated by Visser (1964). Pruning of roots or shoots prolongs the juvenile phase (Zimmerman, 1972).

Hazelnut seedlings bear their first fruit in the 3rd to 6th year, with the 5 th year being in the median. The breeding program at Oregon "State Univ. (OSU) currently operates on an 8-year

Received for publication 24 June 1991. Accepted for publication 2 Dec. 1991 Oregon Agricultural Experiment Station Technical Paper no. 9634. This research was supported with funds from the Oregon Hazelnut Commission. We thank Loretta K. Brenner for technical assistance. The cost of publishing this paper was defrayed in part by the payment of page charges. Under postal regulations, this paper therefore must be hereby marked advertisement solely to indicate this fact. cycle. Nut samples are harvested and evaluated in the 5th to 7th year with annual elimination of inferior seedlings. Superior genotypes are used as parents of the next cycle in the 8th year.

The natural growth habit of hazelnut is that of a multistemmed shrub, but in commercial orchards in Oregon, plants are forced to grow as trees with a single trunk by repeated removal of basal sprouts (suckers) to facilitate mechanization. The effect of this type of training on the precocity of hazelnut seedlings is unknown. The purpose of this experiment was to investigate methods for shortening the juvenile period of hazelnut seedlings.

\section{Materials and Methods}

Controlled crosses were made by standard methods in Winter 1984-85. Emasculated branches were bagged in late November before any trees had begun to shed pollen. Bags were removed, female inflorescences pollinated, and branches rebagged on cool, foggy mornings in January and February when no wind-borne pollen was present. Hybrid nuts were harvested in Aug. 1985, cracked, and kernels were stratified in plastic bags at $4 \mathrm{C}$ to break dormancy. Seeds were planted in flats in the greenhouse when root tips were first visible (January to April); when $\approx 15$ $\mathrm{cm}$ tall, seedlings were transplanted to 3.7-liter pots in a soilless mix of 1 peat : 1 perlite : 1 vermiculite (by volume). Seedlings were grown in the greenhouse under optimum conditions of daily watering and regular fertilization $(9 \mathrm{~g}$ Osmoeote $13 \mathrm{~N}-$ 5.7P-10.8K per pot and Peter's 20N-8.7P-16.6K as needed) throughout the summer, hardened in September, and planted in the field on 22 Ott, 1986 . Seedlings, $\approx 1.5 \mathrm{~m}$ tall, were pruned to a height of $0.9 \mathrm{~m}$ at the time of transplanting. Previous studies indicated that this protocol was superior to field planting of seedlings in the spring or summer of their first year, because growth is immediately arrested at the time of transplanting and does not resume until the following spring (M.M. Thompson, personal communication, 1986). This protocol is also consistent with the recommendation of Zimmerman (1972) that seedlings be handled in a manner such that they quickly attain large size.

Seedlings of four crosses were used in this study: 'Casina' $x$ OSU 55.129, 'Barcelona' $\times$ OSU 55.097, 'Montebello' $\times$ OSU 55.077, and 'Tombul' $\times$ 'Tonda di Giffoni'. All three numbered selections are from the cross 'Tonda Gentile delle Langhe' $\times$ 
'Tombul'. 'Casina' originated in northern Spain, 'Barcelona' in eastern Spain, 'Montebello' in Sicily, 'Tombul' in Turkey, 'Tonda di Giffoni' in southern Italy, and 'Tonda Gentile delle Langhe' in northern Italy. Crosses were made as part of an applied breeding program, the objectives of which were listed by Mehlenbacher (1989).

The design was a split-split plot with spacings as main plots, progenies as subplots, and sucker treatments as sub-subplots. Spacings were used as main plots because the results of Way (1971) indicated that the effect might be highly significant, as well as to facilitate plot layout. There were four replications and 12 seedlings per sub-subplot for a total of 768 seedlings for the experiment. Seedlings were planted by hand at two spacings $(0.6$ and $1.2 \mathrm{~m})$ in rows $3.7 \mathrm{~m}$ apart. Seedlings were planted in guard rows "at a distance of $3.7 \mathrm{~m}$ on either side of the plot, and guard seedlings were planted at the ends of the rows and between main plots within the rows. Nondormant seedlings (Thompson et al., 1985) were replaced with dormant siblings in Mar. 1986. Seedlings were either allowed to grow naturally or suckers were cut off at ground level with pruning shears three or four times during the growing season.

Starting in 1989, 1-1'-dimethyl-4,4'-bipyridinium dichloride (paraquat) herbicide was used for sucker control as recommended for commercial orchards. Fertilizer application rates and procedures for control of weeds and filbertworm (Melissopus latigerannus Wals.) were also as recommended for commercial orchards (Baron et al., 1985). Seedlings were irrigated periodically during the summer months each year.

As the trees began to fruit in their 3rd to 5th year (1988-90), the number of nuts and nut clusters was recorded for each seedlings. Counts were made in early September when the majority of the nuts were ripe but still in the husks on the tree. Means were calculated for number of clusters and nuts per seedling for each sub-subplot and subjected to an analysis of variance (ANOVA). The percentage of seedlings bearing nuts and the percentage of seedlings bearing 10 or more nuts were also calculated and analyzed. Arcsin transformation of percentage data resulted in no change in interpretation, so raw data were used for calculations of means and variances. Seedlings that had not fruited by the 5 th year were inspected in late Winter 1991 and rated for the presence of catkins and female flowers. Those with female inflorescences were recorded as starting to bear nuts in the 6th year. Eight seedlings that produced no female inflorescences in the 6th year were marked as starting to fruit in the 7 th year for calculation of mean years to first fruiting. Means were calculated for each sub-subplot and subjected to ANOVA.

\section{Results}

Although 12 seedlings were planted in each sub-subplot, a few died or were delayed in development \{presumably from bacterial blight [Xanthomonas campestris pv. corylina (Miller et al.) Young et al.]\}. These seedlings, an average of 0.5 per sub-subplot, were eliminated before data analysis.

Spacing produced no detectable differences in percentages of fruiting seedlings, and differences for number of clusters and nuts were significant only in 1990 (Tables 1 and 2). Since cluster counts and nut counts are highly and positively correlated ( $r$ $=\mathbf{0 . 9 5}$ in 1989 and 1990), only nut counts are presented. The wider spacing allowed greater seedling growth and, consequently, greater nut production in 1990, whereas closely planted seedlings became crowded. Seedlings were smaller in 1988 and 1989 and no effect of crowding was detected.

Differences among progenies were statistically significant for all measured traits in all years, indicating large genetic differences in precocity. In 1988, $16.6 \%$ of the seedlings in the progeny 'Barcelona' $\times$ OSU 55.097 fruited, but 'Casina' $\times$ OSU 55.129 surpassed it the following year. All but eight seedlings that failed to fruit in 1990 had female in florescences when inspected in 1991, indicating that they would crop that year. The average number of years to first crop ranged from 4.3 for 'Casina' $\times$ OSU 55.129 to 5.2 for 'Tombul' $\times$ 'Tonda di Giffoni' (Table 3). The 1989 and 1990 data indicate that 'Casina' $\times$ OSU 55.129 was the most precocious progeny and that the other three progenies were similar and less precocious. The progeny $\mathrm{x}$ spacing interaction term was significant $(P=0.025)$ for the percentage of seedlings with nuts in 1990 but not in 1988 or 1989 , or for any other traits. In the progeny 'Tombul' $\times$ 'Tonda di Giffoni', the wider spacing increased the percentage of bearing seedlings from 46 to 69 . Spacing had no effect on the other progenies; thus, the interaction term is statistically significant. Since a significant interaction was detected for only one trait in 1 year and was attributable to only one progeny, spacing appears to be of little practical importance.

In 1990 sucker removal resulted in both a higher percentage of seedlings with nuts and more nuts per seedling. In 1989 sucker removal resulted in a significant $(P=0.04)$ increase in the percentage of seedlings with nuts and had no effect on nut counts. In 1988 no differences due to sucker treatment were detected. Although two or three nuts are sufficient to allow elimination of seedlings with long and very thick-shelled nuts, a minimum of 10 well-filled nuts is needed to reliably assess percent kernel, the amount of fiber on the kernel, and the ease with which the pellicle can be removed with dry heat. Hence, the percentage of seedlings bearing 10 or more nuts is a more useful measure of precocity than is the percentage bearing one or more nuts.

\section{Discussion}

The data and observations of other progenies clearly indicate that genetic variability for precocity exists in hazelnut and that selection of seedlings that begin to bear nuts when young would be effective in reducing the length of the juvenile period. The average length of the juvenile period varied by almost 1 year among the progenies studied, and the juvenile period of individual seedlings varied by 5 years within each progeny. This result is particularly encouraging since there has been intense selection pressure for precocity in the OSU breeding program in recent years and controlled crosses are now primarily among precocious, high-yielding selections.

Sucker removal increased the percentage of seedlings that bear nuts by the 5th year, as well as the number of nuts produced, and shortened the juvenile phase by 3 months. In fruit tree seedlings, pruning delays flowering (Zimmerman, 1972). However, sucker removal differs from pruning in that it increases rather than reduces growth of the main stem, and rapid growth of the main stem would be expected to allow a seedling to enter the adult phase more quickly. Although laborious if done by hand, sucker control with herbicides is possible, particularly on older seedlings.

Wide spacing of seedlings within the row provided additional space for seedling growth and resulted in greater nut production in the 5 th year, but had little or no effect on precocity. The advantages of wide spacing also could be obtained by the removal of undesirable seedlings [e.g., those susceptible to big bud mites (Phytoptus avellanae Nal.)] when young, allowing more desirable siblings to grow more vigorously. Seedlings in 
Table 1. Effect of spacing, progeny, and sucker removal on number of nuts and percentage of hazelnut seedlings bearing nuts. ${ }^{2}$

\begin{tabular}{|c|c|c|c|c|c|c|c|c|c|}
\hline \multirow[b]{2}{*}{ Treatment } & \multirow{2}{*}{$\begin{array}{l}\text { lo. years to } \\
\text { rst fruiting }\end{array}$} & \multicolumn{3}{|c|}{ No. nuts/tree } & \multicolumn{3}{|c|}{$\begin{array}{c}\text { Seedlings bearing } \\
\text { nuts }(\%)\end{array}$} & \multicolumn{2}{|c|}{$\begin{array}{c}\text { Seedlings } \\
\text { bearing } \\
\geq 10 \text { nuts }(\%)\end{array}$} \\
\hline & &, 1988 & $8 \quad 198$ & $39 \quad 1990$ & 1988 & 1989 & 1990 & 1989 & 1990 \\
\hline \multicolumn{10}{|l|}{ Spacing } \\
\hline $1.2 \mathrm{~m}$ & 4.7 & 0.27 & 3.2 & 31.5 & 7.7 & 38.2 & 78.6 & 6.8 & 54.6 \\
\hline $0.6 \mathrm{~m}$ & 4.8 & 0.34 & 1.8 & 17.4 & 6.3 & 33.87 & 72.8 & 5.0 & 40.1 \\
\hline LSD $(5 \%)$ & 0.5 & --- & 1.5 & 11.5 & --- & 22.4 & 7.1 & 5.0 & 16.1 \\
\hline \multicolumn{10}{|l|}{ Progeny } \\
\hline Casina $\times 55.129$ & 4.3 & 0.20 & 7.4 & 48.0 & 4.2 & 72.6 & 94.2 & 20.3 & 74.1 \\
\hline Montebello $\times 55.077$ & 4.9 & 0.16 & 0.8 & 18.9 & 3.4 & 24.97 & 76.0 & 1.7 & 45.1 \\
\hline Barcelona $\times 55.097$ & 4.7 & 0.66 & 0.8 & 17.0 & 16.63 & 31.5 & 75.3 & 0.5 & 36.7 \\
\hline Tombul $\times$ T. di Giffoni & 5.2 & 0.19 & 0.9 & 13.8 & 3.7 & 14.85 & 57.4 & 1.0 & 33.3 \\
\hline $\operatorname{LSD}(5 \%)$ & 0.2 & 0.31 & 2.0 & 11.6 & 5.6 & 9.4 & 8.5 & 4.1 & 13.3 \\
\hline \multicolumn{10}{|l|}{ Sucker treatment } \\
\hline Suckers removed & 4.6 & 0.36 & 2.2 & 32.5 & 7.3 & $39.2 \varepsilon$ & 84.1 & 5.8 & 59.3 \\
\hline With suckers & 4.9 & 0.25 & 2.8 & 16.4 & 6.6 & 32.7 & 67.3 & 6.0 & 35.3 \\
\hline $\operatorname{LSD}(5 \%)$ & 0.1 & --- & 1.4 & 6.2 & --- & 6.1 & 8.2 & 4.9 & 6.3 \\
\hline Overall means & 4.8 & 0.30 & 2.5 & 24.45 & 7.0 & 36.0 & 75.7 & 5.9 & 47.3 \\
\hline
\end{tabular}

${ }^{2}$ Seedlings were grown in the greenhouse during the first year and transplanted to the field in October. The years 1988 to 1990 correspond to the 3rd to 5th year of growth. The means presented were calculated on a sub-subplot basis.

${ }^{y}$ Seedlings that had not fruited by 1990 (year 5) were rated for presence of female inflorescences in late Winter 1991. It was assumed that those with female flowers would crop in 1991 and those without would crop in 1992.

Table 2. Analysis of variance of effect of spacing, progeny, and sucker removal on number of years to first fruiting, number of nuts, and percentage of hazelnut seedlings bearing nuts. ${ }^{2}$

\begin{tabular}{|c|c|c|c|c|c|c|c|c|c|c|}
\hline \multirow[b]{2}{*}{ Source } & \multirow[b]{2}{*}{ df } & \multirow{2}{*}{$\begin{array}{l}\text { No. years } \\
\text { to first } \\
\text { fruiting }\end{array}$} & \multicolumn{3}{|c|}{ No. nuts/tree } & \multicolumn{3}{|c|}{$\begin{array}{c}\text { Seedlings bearing } \\
\text { nuts }(\%)\end{array}$} & \multicolumn{2}{|c|}{ 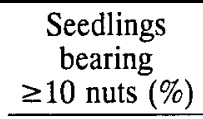 } \\
\hline & & & 1988 & 1989 & 1990 & 1988 & 1989 & 1990 & 1989 & 1990 \\
\hline Reps & 3 & 0.686 & 0.642 & 16 & 3 & 3.7 & 15.7 & 4.4 & 0.3 & 9.6 \\
\hline Spacing (spac) & 1 & 0.328 & 0.080 & 28.12 & $3186.65^{*}$ & 0.3 & 3.1 & 5.4 & 0.5 & 33.7 \\
\hline Error (A) & 3 & 0.391 & 1.117 & 3.51 & 207.21 & 3.7 & 7.9 & 0.8 & 0.4 & 4.1 \\
\hline Progenies (prog) & 3 & $2.447^{* *}$ & $0.928^{* *}$ & $169.28^{* *}$ & $4015.47^{* *}$ & $6.6^{* *}$ & $103.2^{* *}$ & $36.1^{* *}$ & $14.9^{* *}$ & $55.1^{* *}$ \\
\hline Prog $\times$ spac & 3 & 0.104 & 0.037 & 14.11 & 547.83 & 0.3 & 0.4 & $5.1^{*}$ & 0.5 & 1.7 \\
\hline Error (B) & 18 & 0.060 & 0.174 & 7.24 & 244.27 & 0.6 & 1.6 & 1.3 & 0.3 & 3.2 \\
\hline Sucker treatment & 1 & $0.937^{* *}$ & 0.171 & 7.45 & $4158.59^{* *}$ & 0.1 & $6.8^{*}$ & $45.3^{* *}$ & 0.0 & $92.2^{* *}$ \\
\hline Sucker $\times$ spac & 1 & 0.025 & 0.313 & 7.19 & 128.86 & 0.2 & 0.1 & 0.3 & 0.6 & 1.7 \\
\hline Sucker $\times$ prog & 3 & 0.180 & 0.227 & 8.51 & 274.03 & 0.2 & 1.8 & 5.1 & 0.2 & 2.1 \\
\hline Sucker $\times$ spac $\times$ prog & 3 & 0.055 & 0.085 & 1.71 & 264.98 & 0.8 & 0.2 & 1.7 & 0.0 & 3.2 \\
\hline Error (C) & 24 & 0.067 & 0.093 & 7.86 & 143.19 & 0.6 & 1.4 & 2.5 & 0.9 & 1.5 \\
\hline
\end{tabular}

'Seedlings were grown in the greenhouse during the first year and transplanted to the field in October. The years 1988 to 1990 correspond to the 3 rd to 5 th year of growth.

****Significant at $P=0.05$ and 0.01 , respectively.

the OSU breeding program are currently planted at a spacing of $0.9 \mathrm{~m}$, which, coupled with early elimination of undesirable types, appears to be adequate. The $0.6-\mathrm{m}$ spacing was not adequate for optimum seedling growth, nor is it desirable because of the increased likelihood of nut sample mixtures at harvest. Conversely, the $1.2-\mathrm{m}$ spacing appears to waste space, particularly since many seedlings can be eliminated before they fill the allotted space.

The genetic control of precocity has been studied in several tree species. Specific cultivars are known to transmit precocity to their seedlings, while other cultivars have nonprecocious seedlings. For example, seedlings of 'Barlett' pear are precocious while those of 'Maxine' are not (Bell and Zimmerman, 1990), seedlings of 'Haralson' and 'Golden Delicious' apples are precocious while those of 'Northern Spy' and 'Yellow New- town' are not (Way, 1971), and progenies of 'Van' sweet cherry [Prunus avium (L.) L.] are precocious while those of 'Merton Late' are not (Blazek, 1985). General combining ability tends to be much more important than specific combining ability, indicating that gene action is primarily additive in nature (Bell and Zimmerman, 1990; Visser, 1976). Other data indicate that precocity is moderately heritable (Hansche, 1983, 1986).

In certain species, precocity is associated with other characters. In pear, seedlings of 'Max Red Bartlett' that carry the Cardinal Red gene are more precocious than their green-leafed siblings (Zielinski, 1963). In walnut (Juglans regia L.) lateral bearing habit is associated with precocity and productivity (McGranahan and Leslie, 1990). No such relationships have been demonstrated in hazelnut seedling populations, but cultivars such as 'Casina', which set female flowers on catkin pe- 
Table 3. Length of juvenile period in four hazelnut progenies.

\begin{tabular}{lrrrrrrr}
\hline \hline & \multicolumn{4}{c}{$\begin{array}{c}\text { Percentage starting } \\
\text { to bear in } \text { year }^{2, y}\end{array}$} & \multicolumn{2}{c}{$\begin{array}{c}\text { Mean no. } \\
\text { years to }\end{array}$} \\
\cline { 2 - 7 } Progeny & \multicolumn{1}{c}{3} & \multicolumn{1}{c}{4} & \multicolumn{1}{c}{5} & \multicolumn{1}{c}{6} & 7 & first crop \\
\hline Casina X OSU 55.129 & 4.2 & 69.0 & 22.6 & 3.7 & 0.5 & 4.3 \\
Barcelona x OSU 55.097 & 16.6 & 21.2 & 37.7 & 23.9 & 0.6 & 4.7 \\
Montebello x OSU 55.077 & 3.4 & 22.6 & 51.7 & 21.5 & 0.8 & 4.9 \\
Tombul x Tonda di Giffoni & 3.8 & 14.8 & 42.5 & 36.7 & 2.3 & 5.2 \\
Mean & 7.0 & 31.9 & 38.6 & 21.5 & 1.0 & 4.8 \\
\hline
\end{tabular}

${ }^{2}$ Seedlings that had not fruited by 1990 (year 5) were rated for presence of female inflorescences in late Winter 1991. It was assumed that those with female flowers would crop in 1991 and those without would crop in 1992.

'Percentages were calculated for each sub-subplot then averaged over the subplots to obtain progeny means.

duncles, tend to be high-yielding (Makhno, 1984; Mehlenbacher, 1990; Petrosyan and Antonenko, 1974).

Visser (1970) found a positive correlation between apple seedling vigor and precocity and advocated removal of the less vigorous 2- or 3-year-old seedlings based on stem diameter. However, the results of Saure (1970), Zimmerman (1977), and Shen et al. (1982) indicated that such preelection runs a high risk of eliminating precocious seedlings. Although vigor was not measured in this study, such preelection seems inadvisable in hazelnut as well, as there does not seem to be a strong relationship between vigor and precocity. Precocious and highyielding selections with small stature are identified annually.

The OSU hazelnut breeding program currently operates on an 8 -year cycle. Continued selection and use of precocious parents in breeding coupled with sucker removal in seedling plots likely will allow operation on a 7-year cycle in the future.

\section{Literature Cited}

Aldwinckle, H.S. 1975. Flowering of apple seedlings 16-20 months after germination. HortScience 10:124-126.

Baron, L. C., C. Riggert, R.L. Stebbins, and S. Bell. 1985. Growing hazelnuts in Oregon. Oregon State Univ. Ext. Circ. 1219.

Bell, R.L. and R.H. Zimmerman. 1990. Combining ability analysis of juvenile period in pear. HortScience 25:1425-1427.

Blazek, J. 1985. Precocity and productivity in some sweet cherry crosses. Acts Hort. 169:105-113.

Hansche, P.E. 1983. Response to selection, p. 154-171. In: J.N. Moore and J. Janick (eds.). Methods in fruit breeding. Purdue Univ. Press, West Lafayette, Ind.
Hansche, P.E. 1986. Heritability of juvenility in peach. HortScience 21:1197-1198.

Makhno, V.G. 1984. Some aspects of fruit production of hazel in Sochi (in Russian). Subtropicheskie Kul'tury 1984(3):123-130.

McGranahan, G. and C. Leslie. 1990. Walnuts (Juglans), p. 907-951. In: J.N. Moore and J.R. Ballington, Jr. (eds.). Genetic resources of temperature fruit and nut crops. Acts Hort. 290. Intl. Soc. Hort. Sci., Wageningen, The Netherlands.

Mehlenbacher, S.A. 1989. Advances in hazelnut breeding. Annu. Rpt. Northern Nut Growers Assn. 80:30-34.

Mehlenbacher, S.A. 1990. Hazelnuts (Corylus), p. 791-836. In: J.N. Moore and J.R. Ballington, Jr. (eds.). Genetic resources of temperate fruit and nut crops. Acts Hort. 290. Intl. Soc. Hort. Sci., Wageningen, The Netherlands,

Petrosyan, A.A. and G.A. Antonenko. 1974. The role of distillate flower buds on the peduncles of male inflorescenes on the yield of the hazel (in Russian). Vestik Sel'skohozyaistvennoi Nauki 1974(10): 105-107.

Saure, M. 1970. Beitrage zur Frühselektion beim Apfel. I. Beziehungen zwischen dem Eintritt der Blühfahigkeit und der Wuchsleitung von Apfelsamlingen. Mitt. ObstbauVersuchsringes, Jerk 25:156161.

Shen, D. X., Z.L. Li, S.Q. Zheng, H.Q. Chen, and J.B. Lin. 1982. Study of problems in the correlations between growth and juvenility in hybrid seedlings of pear. Acts Hort. Sinica 9(4):27-32.

Thompson, M. M., D.C. Smith, and J.E. Burgess. 1985. Nondormant mutants in a temperate tree species, Corylus avellan L. Theor. Applied Genet. 70:687-692.

Visser, T. 1964. Juvenile phase and growth of apple and pear seedlings. Euphytica 13:119-129.

Visser, T. 1965. On the inheritance of the juvenile period in apple. Euphytica 14:125-134.

Visser, T. 1970. The relation between growth, juvenile period and fruiting of apple seedlings and its use to improve breeding efficiency. Euphytica 19:293-302.

Visser, T. 1976. A comparison of apple and pear seedlings with reference to the juvenile period. H. Mode of inheritance. Euphytica 25:339-342.

Visser, T. and D.P. DeVries. 1970. Precocity and productivity of propagated apple and pear seedlings as dependent on the juvenile period. Euphytica 19:141-144.

Way, R.D. 1971. Hastening the fruiting of apple seedlings. J. Amer. Soc. Hort. Sci. 96:389-391.

Zielinski, Q.B. 1963. Precocious flowering of pear seedlings carrying the Cardinal Red gene. J. Hered. 54:75-78.

Zimmerman, R.H. 1972. Juvenility and flowering in woody plants: A review. HortScience 7:447-455.

Zimmerman, R.H. 1977. Relation of pear seedling size to length of the juvenile period. J. Amer. Soc. Hort. Sci. 102:443-447. 